\title{
DETECTION OF THE DEPTH-HOAR LAYER IN THE SNOW-PACK OF THE ARCTIC COASTAL PLAIN OF ALASKA, U.S.A., USING SATELLITE DATA
}

\author{
By D. K. Hall, A. T. C. Chang, and J. L. Foster
}

(Hydrological Sciences Branch, NASA/Goddard Space Flight Center, Greenbelt, Maryland 20771, U.S.A.)

\begin{abstract}
The snow-pack on the Arctic Coastal Plain of Alaska has a well-developed depth-hoar layer which forms each year at the base of the snow-pack due to upward vapor transfer resulting from a temperature gradient in the snow-pack. The thickness of the depth-hoar layer tends to increase inland where greater temperature extremes (in particular, lower minimum temperatures) permit larger temperature gradients to develop within the snow-pack. Brightness temperature $\left(T_{\mathrm{B}}\right)$ data were analyzed from October through May for four winters using the $37 \mathrm{GHz}$ horizontally polarized Nimbus-7 Scanning Multichannel Microwave Radiometer (SMMR). By mid-winter each year, a decrease in $T_{\mathrm{B}}$ of approximately $20 \mathrm{~K}$ was found between coastal and inland sites on the Arctic Coastal Plain of Alaska. Modeling has indicated that a thicker depth-hoar layer in the inland sites could be responsible for the lower $T_{\mathrm{B}}$ s. The large grain-sizes of the depth-hoar crystals scatter the upwelling radiation moreso than do smaller crystals, and greater scattering lowers the microwave $T_{\mathrm{B}}$. Using a two-layered radiative transfer model, the crystal diameter in the top layer was assumed to be $0.50 \mathrm{~mm}$. The crystals in the depth-hoar layer may be $5-10 \mathrm{~mm}$ in diameter but the effective crystal diameter used in the radiative-transfer model is $1.40 \mathrm{~mm}$. The crystal size used in the model had to be adjusted downward, relative to the actual crystal size, because the hollow, cup-shaped depth-hoar crystals are not as effective at scattering the microwave radiation as are spherical crystals that are assumed in the model. In the model, when the thickness of the depth-hoar layer was increased from $5 \mathrm{~cm}$ to $10 \mathrm{~cm}$, a $21 \mathrm{~K}$ decrease in $T_{\mathrm{B}}$ resulted. This is comparable to the decrease in $T_{\mathrm{B}}$ observed from coastal to inland sites in the study area.
\end{abstract}

RÉsumé. Détection de la couche de givre de profondeur dans la couverture nivale de la plaine côtière arctique de l'Alaska, USA, à l'aide de données satellitaire. La couche de neige de la plaine cotière arctique de l'Alaska possède un niveau bien marqué de givre de profondeur qui se forme chaque année à sa base, sous l'effet du transfert ascendant de vapeur da au gradient vertical de température. L'épaisseur de cette couche de givre de profondeur a tendance à croître vers l'intérieur des terres où des températures extrêmes plus importantes (en particulier, un minimum plus bas) induisent des gradients plus important dans la couche de neige. Les données de température de brillance $\left(T_{\mathrm{B}}\right)$ ont été analysées d'octobre à mai pendant quatre hivers en utilisant le radiomètre à micro ondes multicanaux à polarisation horizontale de $37 \mathrm{GHz}$ (SMMR) de Nimbus-7. Chaque année à la mi-hiver, une décroissance de $T_{\mathrm{B}}$ d'environ $20 \mathrm{~K}$ a été trouvée entre les sites côtiers et ceux de l'intérieur dans la plaine cotière arctique de l'Alaska. Une modélisation indique qu'une couche de givre de profondeur plus épaisse dans les sites intérieurs peut être responsable de ce $T_{\mathrm{B}}$ plus faible. La grande taille des cristaux de givre de profondeur disperse le rayonnement vers le haut plus que ne le font de petits cristaux et une dispersion plus importante abaisse la température de brillance. Dans le modèle de transfert radiatif à deux couches, le diamètre des cristaux à la partie supérieure de la couche de neige a été supposé égal à $0,50 \mathrm{~mm}$. La taille des cristaux à l'intérieur de la couche de givre de profondeur peut atteindre 5 à $10 \mathrm{~mm}$, mais le diamètre effectif adopté pour le modèle de transfert radiatif est de $1,40 \mathrm{~mm}$. La taille des cristaux adoptée pour la modélisation doit être plus faible que la taille réelle des cristaux, parce que les cristaux de givre, creux, en gobelets, ne dispersent pas le rayonnement de la même façon que les cristaux sphériques du modèle. Pour le modèle, une augmentation de l'épaisseur de la couche de givre de profondeur de 5 à $10 \mathrm{~cm}$ conduit à une diminution de $T_{\mathrm{B}}$ de $21 \mathrm{~K}$. Ceci est comparable à la diminution de $T_{\mathrm{B}}$ observée de la côte à l'intérieur de la zone étudiée.

ZuSAMmenfassung. Ermittlung der Tiefenreif-Schicht in der Schneedecke der arktischen Küstenebene von Alaska, USA, mit Hilfe von Satellitendaten. Die Schneedecke über der arktischen Küstenebene von Alaska weist eine gut entwickelte Schicht von Tiefenreif auf; sie bildet sich jedes Jahr am Grunde der Schneedecke infolge eines nach oben gerichteten Dampfstromes, der durch einen Temperaturgradienten in der Schneedecke entsteht. Die Dicke der Tiefenreifschicht neigt zu einer Zunahme landeinwärts, wo grössere Temperaturspannen (besonders geringere MinimalTemperaturen) die Entwicklung stärkerer Temperaturgradienten zulassen. Für vier Winter zwischen Oktober und Mai wurden Daten der Helligkeitstemperatur $T_{\mathrm{B}}$, gewonnen mit dem horizontal polarisierten, multispektralen $37 \mathrm{GHz}-$ Mikrowellen-Abtastradiometer (SMMR) von Nimbus-7, analysiert. Im Hochwinter jeden Jahres zeigt sich eine Abnahme von $T_{\mathrm{B}}$ um ca. $20 \mathrm{~K}$ zwischen küstennahen und landein gelegenen Stellen auf der arktischen Küstenebene von Alaska. Modellrechnungen weisen darauf hin, dass eine dickere Tiefenreifschicht über den landein gelegenen Stellen für diese tieferen Werte von $T_{\mathrm{B}}$ verantwortlich sein könnte. Die grősseren Körner der Tiefenreifkristalle zerstreuen die zurückgeworfene Strahlung mehr als kleinere Kristalle; grössere Streuung aber vermindert die $T_{\mathrm{B}}$ der Mikrowellen. Aus einem Zwei-Schichten-Modell für den Strahlungstransport ergab sich für die obere Schicht ein Kristalldurchmesser von $0,50 \mathrm{~mm}$. Die Kristalle in der Tiefenreifschicht mögen 5-10 mm Durchmesser haben, aber der effektive Kristalldurchmesser, der in das Modell eingeführt wurde, ist $1,40 \mathrm{~mm}$. Die im Modell benutzte Kristallgrösse musste relativ zur tatsăchlichen Kristallgrösse nach unten verăndert werden, weil die hohlen, tassenförmigen Tiefenreifkristalle eine geringere Streuung der Mikrowellenstrahlung bewirken als die im Modell angenommenen sphărischen Kristalle. Wurde im Modell die Dicke der Tiefenreifschicht von $5 \mathrm{~cm}$ auf $10 \mathrm{~cm}$ erhø̋t, so ergab sich eine Abnahme von $T_{\mathbf{B}}$ um $21 \mathrm{~K}$. Dieser Wert ist mit der Abnahme von $T_{B}$ vergleichbar, die zwischen küstennahen und landein gelegenen Stellen des Untersuchungsgebietes beobachtet wurde. 


\section{INTRODUCTION}

Snow is a major component of the regional and global energy balance because of its high albedo and of ten rapid disintegration. Utilization of passive microwave data is suitable for analysis of snow-covered area and snow depth. The influence of snow structure on the microwave brightness temperature $T_{B}$ must be understood in order to measure (and model) snow depth as an input to energy-balance models.

The transformation of fallen snow into a snow-pack with a definite structure is the result of local and regional energy-balance processes. When snow remains on the ground for a substantial part of the winter, metamorphism at the base of the snow-pack can result in the formation of a layer comprised of large, loosely bonded crystals known as depth hoar. Depth hoar is common in snow-packs throughout the world and is well developed in parts of Alaska.

On the Arctic Coastal Plain of Alaska (Fig. 1), low snow accumulation, very cold air temperatures, and strong winds contribute to the snow-pack structure. A relatively thin, continuous snow cover forms each year. Once the snow is deposited, little additional accumulation or melting occurs until spring. High average snow-pack densities result from intense redistribution of the snow by wind, causing the crystals to be rounded and abraded, thus facilitating compaction in the upper part of the snow-pack.

The specific structure of the snow-pack on the Arctic Coastal Plain consists of a high-density $\left(0.35-0.45 \mathrm{~g} \mathrm{~cm}^{-3}\right)$, wind-packed surface layer overlying a low-density $\left(0.20-0.30 \mathrm{~g} \mathrm{~cm}^{-3}\right)$ depth-hoar layer with transitional layers in between. In the depth-hoar layer, snow-crystal sizes are large and the crystals are loosely bonded. This layer can comprise $50 \%$ of the thickness of the snow-pack on the Arctic Coastal Plain (Benson and others, 1975).

In this paper, theoretical and observational data indicate that the presence and relative thickness of the depth-hoar layer on the Arctic Coastal Plain of Alaska can be detected by microwave sensors. By observing variations in the responses of microwave sensors and utilizing available meteorological data, one can infer differences in depth-hoar development between coastal and inland sites. Using a two-layered radiative-transfer model, the relationship between grain-size in the depth-hoar layer and microwave response is shown. Also shown is the effect that a thicker depth-hoar layer has on microwave response.

\section{DEVELOPMENT OF THE DEPTH-HOAR LAYER}

The difference between the temperature of the soil (at the base of the snow-pack) and the air temperature can be greater than $40 \mathrm{deg}$ in northern Alaska (Slaughter and Crook, 1974). This results in a steep negative temperature gradient in the snow-pack because the temperature at the base of the snow-pack can be $-5^{\circ} \mathrm{C}$. At the surface of the snow-pack the temperature can be $-45^{\circ} \mathrm{C}$. Early snow accumulation, such as occurs on the Arctic Slope of Alaska, promotes greater retention of ground heat at the base of the snow-pack (Santeford, 1979). In addition, shallow snow has the potential for steeper temperature gradients than does deep snow (Benson and Trabant, 1973). Snow crystals sublime and the vapor is redeposited on to adjacent crystals in an upward direction in a process called constructive metamorphism (Giddings and LaChapelle, 1962). Faster crystal growth occurs in the warmer (lower) parts of the snow-pack (Colbeck, 1982[b]).

There are two basic types of snow-pack metamorphism: constructive and destructive metamorphism. In the latter case, snow crystals become rounded and are reduced in size allowing compaction which results in increasing density. An illustration of destructive metamorphism is shown in Figure 2.

Conversely, constructive metamorphism occurs when snow-crystal size increases through time. Crystals grow from one side of existing snow crystals or grains in a direction that is opposite to the vapor-pressure gradient; the same grains lose material by sublimation on the other side. Constructive metamorphism of snow crystals leads to development of depth hoar - increasingly large crystals in

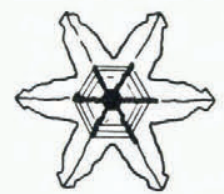

0

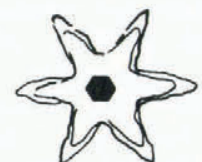

2

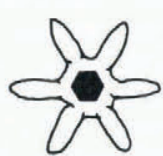

5

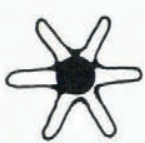

10

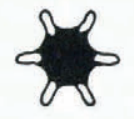

21

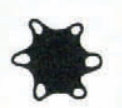

28

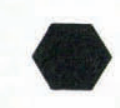

45

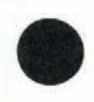

54
Fig. 2. Illustration showing destructive metamorphism (after Colbeck, 1982[b]).

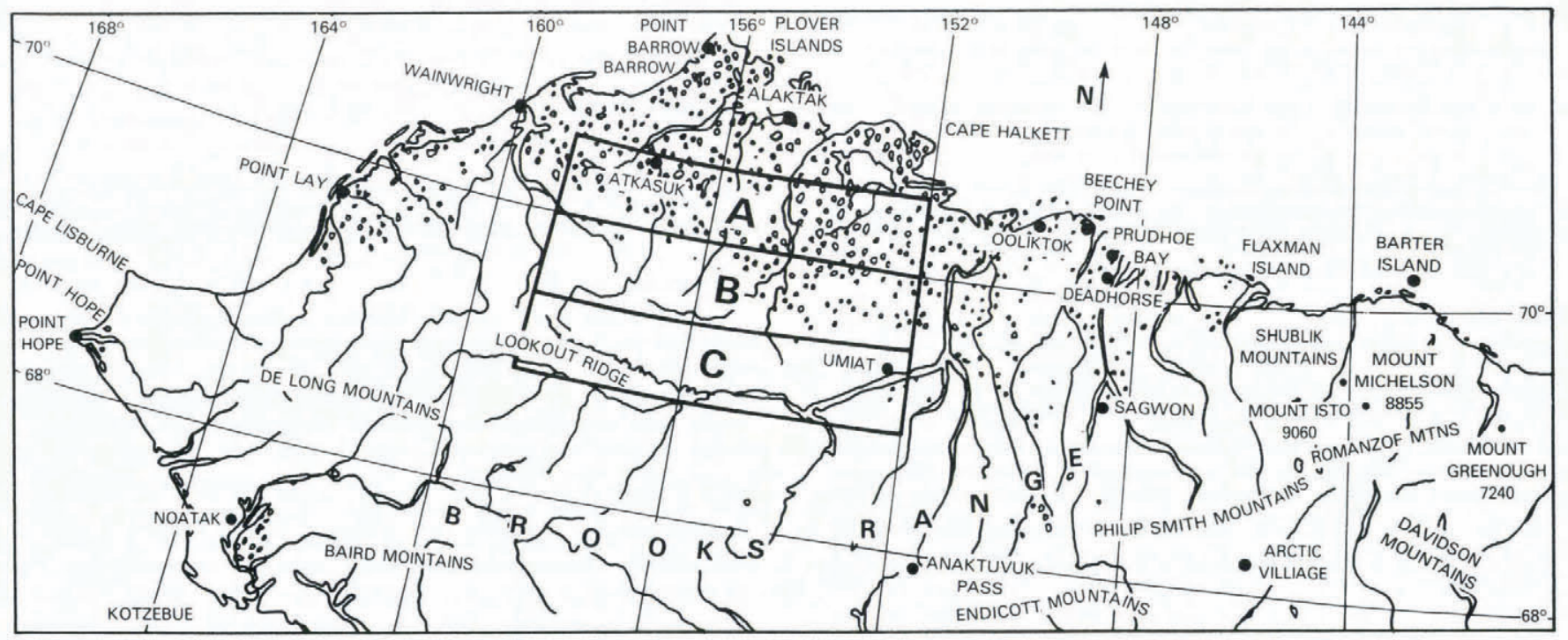

Fig. 1. Arctic Coastal Plain of Alaska showing study areas A, B, and C. 


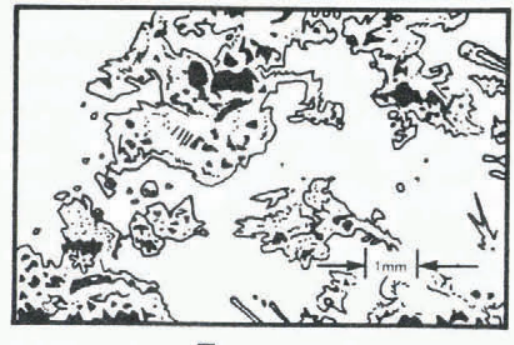

5

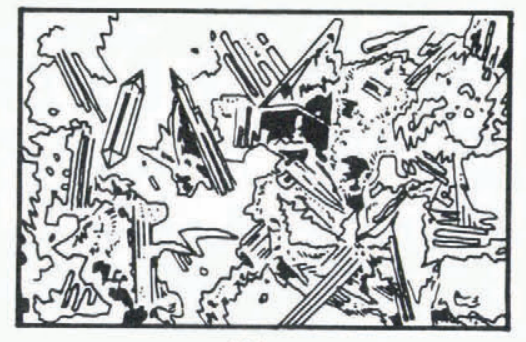

20

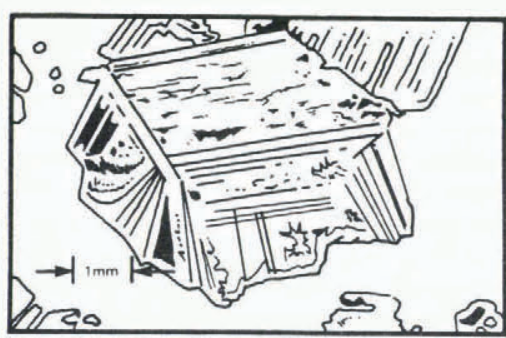

26

Fig. 3. Illustration showing constructive metamorphism.

the lower layers of the snow-pack. Density per unit volume decreases. Depth-hoar formation is complete when initial snow grains have been completely replaced by the depthhoar crystals (Giddings and LaChapelle, 1962). This is illustrated in Figure 3. Such crystals or grains can be $5-10 \mathrm{~mm}$ in diameter (Benson and others, 1975). The depth-hoar crystals are hollow and cup-shaped.

The temperature gradient produces inequalities in the degree of air saturation and the diffusion rate of water vapor (Marbouty, 1980). Associated pressure gradients cause water vapor to diffuse from warmer to colder parts of a snow-pack (Langham, 1981). A local temperature gradient within the snow-pack of $0.1-0.2 \mathrm{deg} / \mathrm{cm}$ is sufficient to initiate the formation of depth-hoar crystals (Colbeck, 1982[a]).

The presence of the depth-hoar layer weakens the overall strength of the snow-pack and is often responsible for the failure of snow slabs which can result in avalanches in mountainous areas (Marbouty, 1980).

\section{THEORETICAL BASIS FOR MICROWAVE OBSERVA- TIONS}

Satellite data are useful for analyzing snow conditions on regional and global scales, and microwave sensors are able to acquire data through cloud cover and darkness. Passive microwave sensors which sense the emitted radiation can provide information regarding the internal characteristics of snow and ice (Chang and others, 1976). Previous studies have shown that there is an inverse relationship between snow depth and microwave $T_{\mathrm{B}}$ as measured by passive microwave sensors at specified ${ }^{B}$ wavelengths in dry snow (Foster and others, 1984). The $37 \mathrm{GHz}(0.81 \mathrm{~cm}$ wavelength) sensor of the Scanning Multichannel Microwave Radiometer (SMMR) on board the Nimbus-7 satellite has been shown to be particularly useful for analyzing internal properties of snow-packs especially when the horizontally polarized data are used (Hall and others, 1984). Some characteristics of the Nimbus-7 SMMR are shown in Table I.

For temperatures generally encountered on Earth, the emitted intensity of microwave radiation is expressed as brightness temperature $\left(T_{\mathrm{B}}\right)$ in degrees Kelvin and follows the Rayleigh-Jeans approximation which shows that the radiance from a black body is proportional to its temperature.

$$
T_{\text {B }}=\epsilon T_{\mathrm{s}} \mathrm{e}^{-\tau}+T_{1}+(1-\epsilon) T_{2} \mathrm{e}^{-\tau}+(1-\epsilon) T_{s p} \mathrm{e}^{-2 \tau}
$$

where $\epsilon$ is the emissivity of the surface, $T_{\mathrm{S}}$ is the sensible temperature of the surface, $\tau$ is the total atmospheric opacity, $T_{1}$ is the upward-emitted radiance contribution of the atmosphere, $T_{2}$ is the total downward (emitted and reflected) atmospheric brightness temperature, and $T_{\mathrm{sp}}$ is the average temperature of free space (Gloersen and Barath, 1977).

Chang and others (1976) calculated that the radiation emanates from a depth, in snow and firn, that is 10 to 100 times the length of the wavelength used. Measurement of the amount of sub-surface emission and the depth from which it emanates is dependent on the physical characteristics of the snow or ice as well as on instrument parameters.

Studies of the brightness temperatures of the Greenland and Antarctic ice sheets as determined from the Nimbus-5 Electrically Scanned Microwave Radiometer (ESMR) data revealed large variations in brightness temperature across the ice sheets that did not correlate with physical surface temperature in Greenland and correlated only loosely with surface temperature in Antarctica (Chang and others, 1976). Observation and modeling have shown that differences in emissivity are related to variations in snow accumulation rates, mean annual temperature, and melting effects on the ice sheets (Zwally and Gloersen, 1977). Specifically, larger grain-sizes in ice-sheet locations having low accumulation rates are known to cause more scattering and to be associated with lower microwave emissivities.

Calculations have shown that the grain or crystal size is a dominant factor influencing the microwave emission of snow and dry polar firn. Additional calculations using a microscopic scattering model for snow have shown that the scattering of $37 \mathrm{GHz}$ radiation from a snow-pack is strongly dependent upon the grain-size of the snow particles (Chang and others, 1982).

As snow grain-size increases, microwave $T_{\mathrm{B}}$ of a given snow-pack should decrease if other parameters remain the same (Chang and others, 1982). Increasing grain-size within the snow-pack allows greater incidence of scattering of microwave radiation as the grain-size approaches or surpasses the size of the wavelength. The large crystals characterizing the depth-hoar layer would tend to increase scattering of the upwelling radiation relative to scattering through a snow-pack (with a similar thickness) which is lacking a depth-hoar layer.

\section{METHODOLOGY}

For this study, Nimbus-7 SMMR data of northern Alaska were acquired and analyzed for four winters:

TABLE I. SOME CHARACTERISCTICS OF THE SMMR (AFTER GLOERSEN AND BARATH, 1977)

$\begin{array}{lccccc}\text { Wavelength }(\mathrm{cm}) & 0.81 & 1.43 & 1.66 & 2.80 & 4.54 \\ \text { Frequency (GHz) } & 37.00 & 21.00 & 18.00 & 10.69 & 6.60 \\ \text { Spatial resolution }(\mathrm{km}) & 30 & 60 & 60 & 97.5 & 156 \\ \begin{array}{l}\text { Temperature resolution } \\ { }_{\text {rms }}(\mathrm{K}) \text { (per IFOV) }\end{array} & 1.5 & 1.5 & 1.2 & 0.9 & 0.9 \\ \text { Antenna beam width (degree) } & 0.8 & 1.4 & 1.6 & 2.6 & 4.2\end{array}$


1979-80, 1980-81, 1981-82, and 1982-83. Data were analyzed from 1 October through 31 May. Data from all available night-time SMMR overpasses were used at the $37 \mathrm{GHz}$ wavelength, horizontal polarization. Each brightness temperature value is an average of six night-time overpasses. Three areas within northern Alaska were analyzed and these are shown in Figure 1. Each area comprises 15 SMMR pixels. The resolution of each pixel in this study is $1 / 2$ degree longitude $\times 1 / 2$ degree latitude. The 15 SMMR pixels were averaged to obtain a mean brightness temperature value for each night-time satellite overpass within areas $\mathrm{A}, \mathrm{B}$, and $\mathrm{C}$.
Snow-depth and air-temperature data of Barrow, Alaska, were used for area $\mathrm{A}$, the northernmost area shown in Figure 1. The meteorological station located at Umiat, Alaska, was within the southernmost area, or area $C$, and was considered representative of area C. No station was used to represent meteorological and snow-depth conditions in area $\mathbf{B}$.

\section{OBSERVATIONAL RESULTS}

Figures 4, 5, 6, and 7 show graphs of $37 \mathrm{GHz}$ horizontally polarized $T_{\mathrm{B}}$ for three study areas on the

\section{$1979-80$}

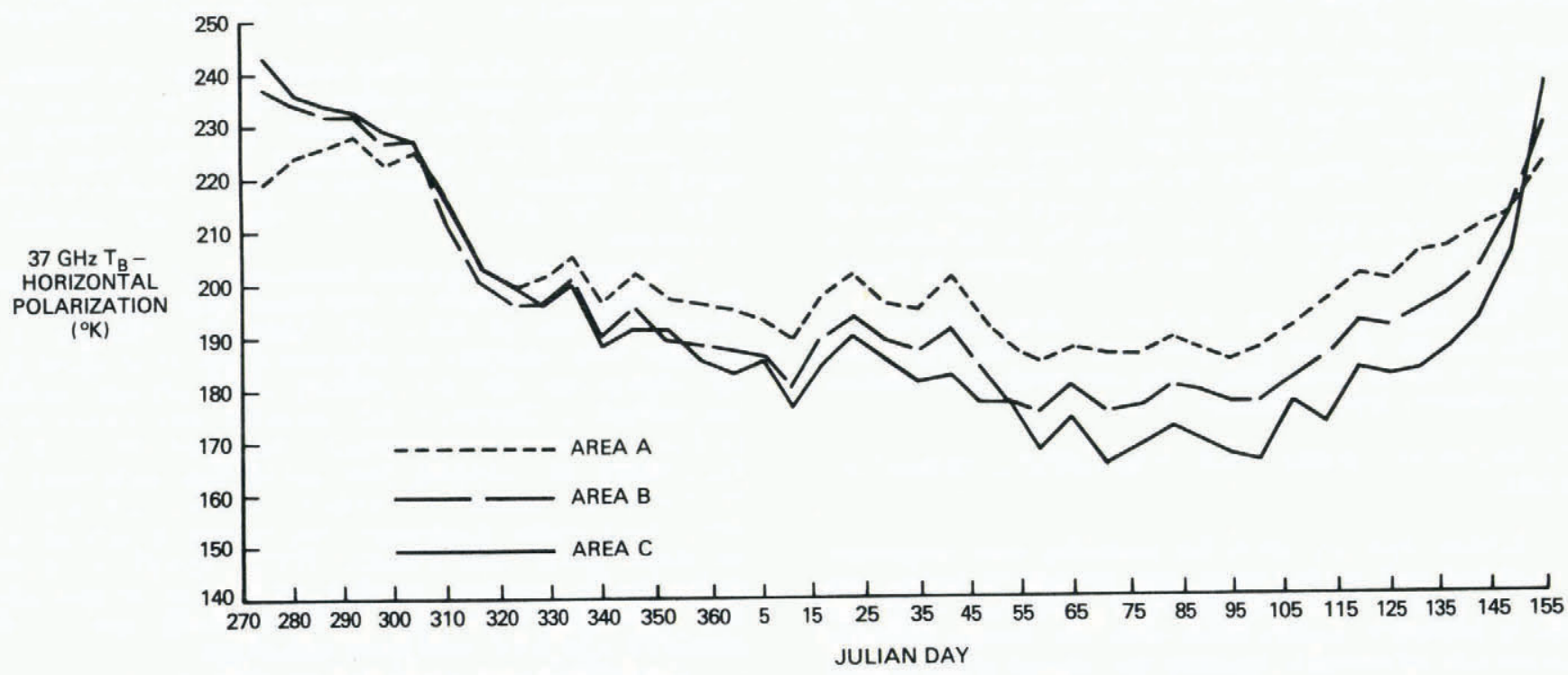

Fig. 4. SMMR $37 \mathrm{GHz}$ horizontally polarized brightness temperatures for areas A, B, and C (from Fig.

1) from October 1979 through May 1980.

\section{$1980-81$}

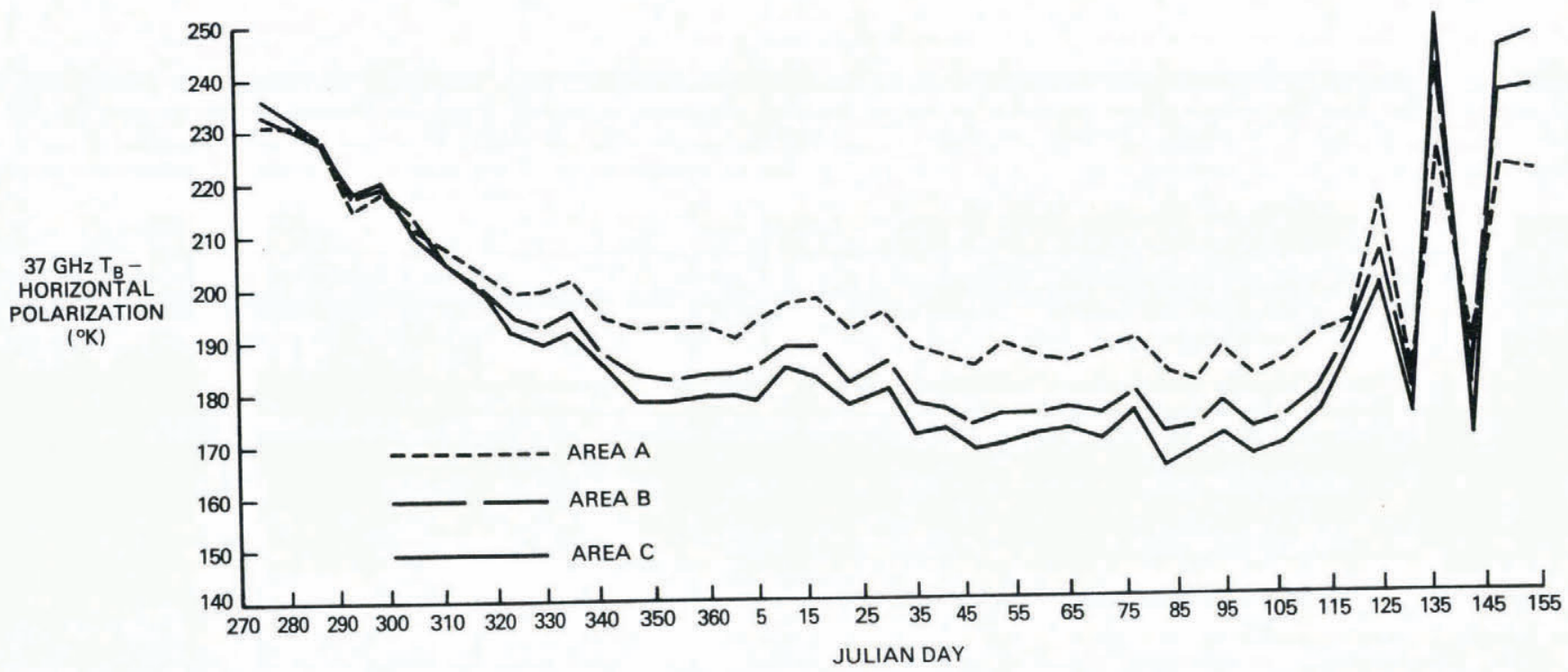

Fig. 5. SMMR $37 \mathrm{GHz}$ horizontally polarized brightness temperatures for areas $A, B$, and $C$ (from Fig.

1) from October 1980 through May 1981. 


\section{$1981-82$}

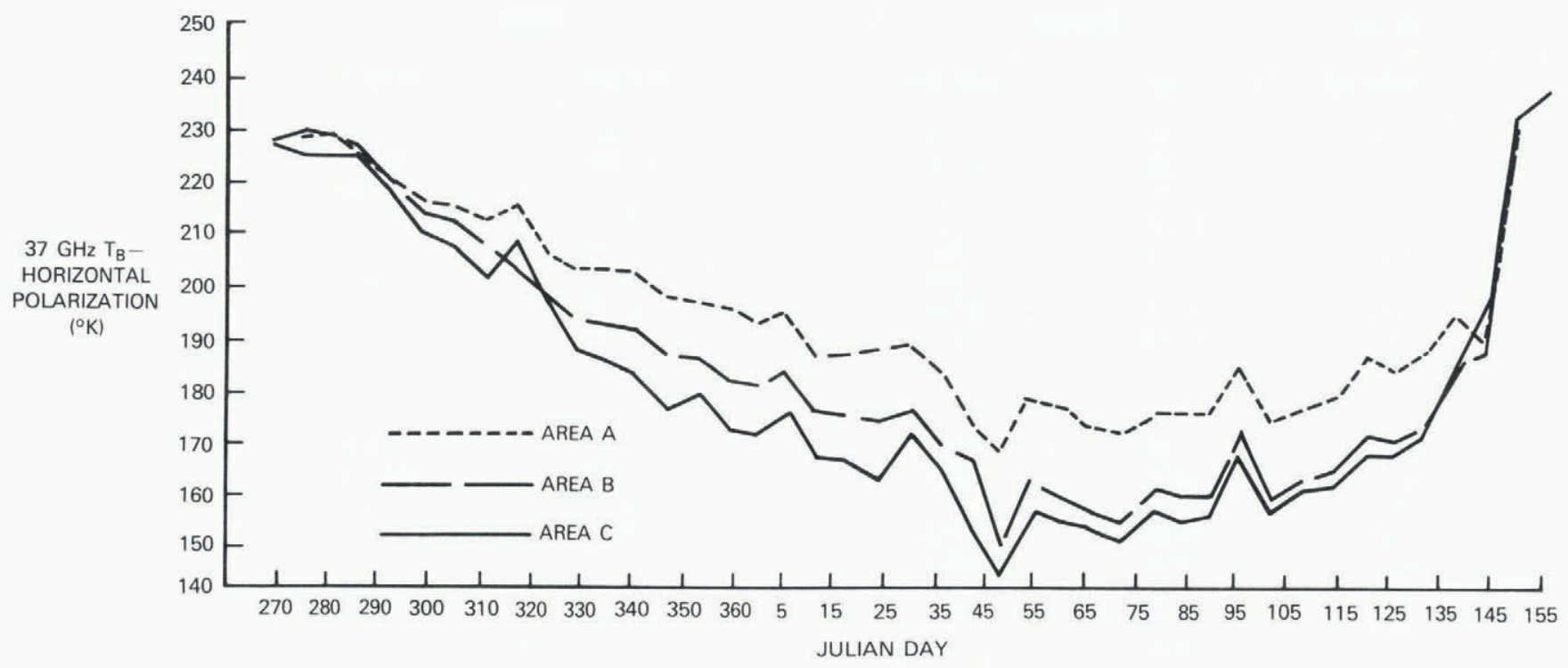

Fig. 6. SMMR $37 \mathrm{GHz}$ horizontally polarized brightness temperatures for areas A, B, and $C$ (from Fig.

1) from October 1981 through May 1982.

\section{2-83}

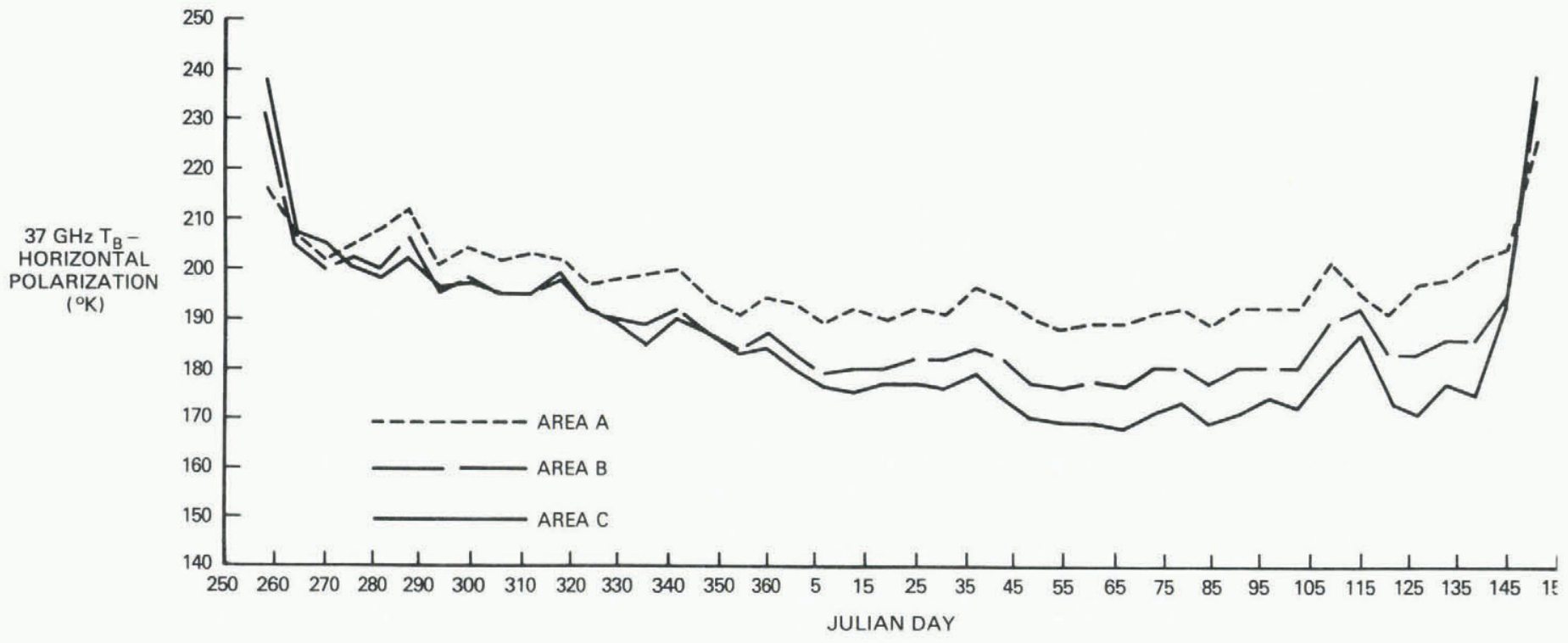

Fig. 7. SMMR $37 \mathrm{GHz}$ horizontally polarized brightness temperatures for areas A, B, and C (from Fig.

1) from October 1982 through May 1983.

Arctic Coastal Plain of Alaska for four winters: 1979-80, 1980-81, 1981-82, and 1982-83. Note that in each winter, $T_{\mathrm{B}} \mathrm{S}$ decrease in the latter half of the winter especially in areas $\mathrm{B}$ and $\mathrm{C}$. Once snow is on the ground, areas $\mathbf{A}$ and $\mathrm{B}$ have consistently higher $T_{\mathrm{B}} \mathrm{s}$ than area C. Average air temperatures at Umiat were somewhat lower than at Barrow (Table II), and the temperture extremes are greater at Umiat than at Barrow because of the more continental location of the Umiat station. This can be seen in Table II by noting that the standard deviations are higher for the Umiat data than for the Barrow data (NOAA, 1979-83).

In the present study area, the lower $T_{\mathrm{B}}$ in areas $\mathrm{B}$ and $C$ is apparently not the result of deeper snow. Though previous work has shown that under certain conditions there is an inverse relationship between snow depth and microwave brightness temperature (Rango and others, 1979), exceptions to this are many (Foster and others, 1984). Table III shows that snow depths were generally greater at Umiat than at Barrow, but not always. For example, the average February through April 1980 snow depth was $35.80 \mathrm{~cm}$ at Barrow and $30.70 \mathrm{~cm}$ at Umiat. But the $T_{\mathrm{B}} \mathrm{s}$ shown in Figure 4 were consistently lower in area $\mathrm{C}$ where the Umiat station is located.

A thicker depth-hoar layer in the more interior areas (areas B and C) would explain the lower $T_{\mathrm{B}} \mathrm{S}$ as it is known that depth-hoar development is more pronounced in 
TABLE II. MONTHLY AVERAGE AIR TEMPERATURES $\left({ }^{\circ} \mathrm{C}\right)$ AND STANDARD DEVIATION AT BARROW AND UMIAT, ALASKA, 1979-83 (NOAA, 1979-83)

\begin{tabular}{|c|c|c|c|c|}
\hline \multirow{2}{*}{$\begin{array}{l}\text { Winter } \\
1979-80\end{array}$} & \multicolumn{2}{|c|}{ Barrow } & \multicolumn{2}{|c|}{ Umiat } \\
\hline & Average & Std Dev. & Average & Std Dev. \\
\hline Oct. & -7.26 & 5.670 & -8.82 & 4.536 \\
\hline Nov. & -12.50 & 6.216 & -13.09 & 8.173 \\
\hline Dec. & -24.42 & 6.181 & -29.96 & 10.246 \\
\hline Jan. & -25.51 & 7.233 & -28.28 & 15.240 \\
\hline Feb. & -23.45 & 7.952 & -25.06 & 11.286 \\
\hline Mar. & -24.18 & 3.048 & -24.75 & 7.338 \\
\hline Apr. & -19.86 & 3.764 & -20.01 & 6.180 \\
\hline May & -8.36 & 4.807 & -5.63 & 6.117 \\
\hline \multicolumn{5}{|l|}{$1980-81$} \\
\hline Oct. & -9.76 & 3.391 & -10.69 & 29.648 \\
\hline Nov. & -20.56 & 4.961 & -22.83 & 15.812 \\
\hline Dec. & -26.40 & 6.921 & -29.40 & 8.671 \\
\hline Jan. & -18.29 & 3.854 & -18.69 & 4.314 \\
\hline Feb. & -26.51 & 4.813 & -29.93 & 11.205 \\
\hline Mar. & -23.84 & 5.409 & -25.19 & 6.313 \\
\hline Apr. & -17.17 & 4.900 & -17.68 & 5.776 \\
\hline May & -4.69 & 3.739 & \multicolumn{2}{|c|}{ Missing data } \\
\hline \multicolumn{5}{|l|}{$1981-82$} \\
\hline Oct. & -9.92 & 3.443 & \multirow{3}{*}{\multicolumn{2}{|c|}{$\begin{array}{l}\text { Missing data } \\
\text { Missing data } \\
\text { Missing data }\end{array}$}} \\
\hline Nov. & -18.10 & 5.699 & & \\
\hline Dec. & -22.25 & 4.921 & & \\
\hline Jan. & -23.94 & 3.615 & -32.05 & 10.980 \\
\hline Feb. & -21.36 & 11.455 & -24.09 & 22.583 \\
\hline Mar. & -24.64 & 4.183 & -27.22 & 10.577 \\
\hline Apr. & -18.33 & 6.009 & -18.74 & 8.172 \\
\hline May & -8.58 & 4.976 & -6.52 & 7.083 \\
\hline \multicolumn{5}{|l|}{$1982-83$} \\
\hline Oct. & -13.93 & 5.208 & -15.08 & 6.848 \\
\hline Nov. & -23.39 & 2.687 & -27.09 & 19.817 \\
\hline Dec. & -22.91 & 5.268 & -29.82 & 15.359 \\
\hline Jan. & -28.43 & 5.549 & -35.22 & 12.382 \\
\hline Feb. & -26.29 & 5.236 & -32.40 & 5.439 \\
\hline Mar. & -25.18 & 3.967 & -32.20 & 5.600 \\
\hline Apr. & -16.30 & 6.792 & -17.94 & 15.350 \\
\hline May & -8.41 & 3.444 & -6.33 & 6.402 \\
\hline
\end{tabular}

TABLE III. MONTHLY AVERAGE SNOW ON THE GROUND (cm) AT BARROW AND UMIAT, ALASKA, 1979-83 (NOAA, 1979-83)

\begin{tabular}{|c|c|c|c|c|c|c|c|c|c|}
\hline $1979-80$ & Oct. & Nov. & Dec. & Jan. & Feb. & Mar. & Apr. & May & Average \\
\hline Barrow & 6.64 & 13.97 & 19.58 & 22.70 & 36.52 & 40.64 & 27.26 & $\begin{array}{r}8.44 \\
14.34\end{array}$ & 21.97 \\
\hline Umiat & 15.57 & 21.25 & 19.42 & 20.89 & 31.36 & 29.25 & & & \\
\hline \multicolumn{10}{|l|}{$1980-81$} \\
\hline Barrow & 17.86 & 29.80 & 31.79 & 32.20 & 32.57 & 25.81 & 26.33 & 7.46 & 25.48 \\
\hline Umiat & 16.06 & 17.78 & 18.03 & 35.31 & 40.64 & 39.98 & 35.56 & 5.29 & 26.08 \\
\hline \multicolumn{10}{|l|}{$1981-82$} \\
\hline Barrow & 4.68 & 17.78 & 17.78 & 19.99 & 26.85 & 32.12 & 33.95 & 21.55 & 21.84 \\
\hline Umiat & 11.88 & 28.36 & 31.55 & 29.66 & 31.75 & 33.43 & 35.66 & 30.48 & 29.06 \\
\hline \multicolumn{10}{|l|}{$1982-83$} \\
\hline Barrow & 8.52 & 10.16 & 10.16 & 12.70 & 14.51 & 15.24 & 14.39 & 4.42 & 11.26 \\
\hline Umiat & 7.46 & 14.39 & 19.66 & 26.67 & 28.03 & 30.48 & 24.72 & 3.77 & 19.40 \\
\hline
\end{tabular}


inland areas (Slaughter and Crook, 1974). In addition, the crystal sizes in the depth-hoar layer may become larger as the winter progresses (Giddings and LaChapelle, 1962); the separation in $T_{\mathrm{B}}$ (between areas $\mathrm{A}$ and $\mathrm{B}$, and $\mathrm{B}$ and $\mathrm{C}$ ) becomes greater as the winter progresses, indicating an increase in (1) size of depth-hoar crystals, and/or (2) thickness of the depth-hoar layer.

The differences in $T_{\mathrm{B}}$ (among areas $\mathrm{A}, \mathrm{B}$, and $\mathrm{C}$ ) do not show up until snow was on the ground as seen in Figures 4 through 7 . Thus, the change in $T_{B}$ is clearly related to the presence of snow cover.

Colder air temperatures are conducive to greater depthhoar development within a snow-pack because the potential temperature gradient within the snow-pack is higher, causing the vapor-pressure gradient to be greater as well. Vapor-pressure gradients within the snow-pack are larger in more continental climates (Slaughter and Crook, 1974). Thus, one would expect depth-hoar development to be greater in area $\mathbf{C}$ than in area $\mathbf{A}$ because of colder minimum air temperatures in area C. As mentioned earlier, larger grain-sizes (characteristic of depth hoar) are concomitant with increased scattering and thus lower brightness temperatures and more radiational scattering.

The presence of sea ice near the coast of northern Alaska during the winter changes the maritime climate of the coastal areas to a climate that is more similar to an inland or continental climate. The effect of continentality is evident only a few kilometers inland from the Arctic Ocean and it rapidly becomes more pronounced farther inland; Brown and others (1975) referred to the winter coastal stations as having "near-continental" temperature patterns.

Sea ice slows the release of latent heat from the ocean to the atmosphere. The presence of leads (linear features of open water) within the sea ice permits increases in heat flux while open because the heat flux through open water can be 100 times greater than through thick ice (Weeks, 1981). In addition, the pack ice has a lower reflectivity than fresh snow in the visible and near-infrared parts of the spectrum than the adjacent snow-covered tundra because of ice-surface roughness, pressure ridges, and hummocks (Holmgren and others, 1974). Thus, the absorption and emission characteristics of the sea ice are different from those of the land surface particularly during the daylight hours in the spring and fall. The winter climate of the coastal part of the Arctic Slope is neither truly maritime nor truly continental.

No direct measurements were obtained during this study period to confirm the theory that depth hoar is better developed in area $\mathrm{C}$ as compared to areas $\mathrm{A}$ and $\mathrm{B}$. However, model results (see next section) show that the difference in brightness temperature between coastal and inland sites can be accounted for by increasing the thickness of the depth-hoar layer in more inland sites.

\section{MODEL RESULTS}

The intensity of microwave radiation emitted from a snow-pack depends on the physical temperature, grain-size, density, and the underlying surface conditions of the snow-pack. By knowing these parameters, the radiation emerging from a snow-pack can be derived by solving the radiative-transfer equation. The radiative-transfer equation for an axially symmetric inhomogeneous medium can be written in the form of an integro-differential equation

$$
\begin{aligned}
\mu \frac{\mathrm{d} I(x, \mu)}{\mathrm{d} x} & =-\sigma(x) I(x, \mu)+\sigma(x)\{[I-\omega(x)] B(x)+ \\
& \left.+\frac{1}{2} \omega(x) \int_{-1}^{1} P\left(x, \mu, \mu^{\prime}\right) I\left(x, \mu^{\prime}\right) \mathrm{d} \mu^{\prime}\right\}
\end{aligned}
$$

where the radiation intensity $I(x, \mu)$ is at a depth $x$ and traveling in the direction towards increasing $x$, making an angle whose cosine is $\mu$ with the normal (Chang and others, 1982). The functions $\sigma(x), \omega(x), B(x)$, and $P\left(x, \mu, \mu^{\prime}\right)$ are prescribed functions of their arguments. They are the extinction per unit length, the single scattering albedo, and the source and phase functions, respectively.
Equation (2) is solved numerically using an invariant imbedding technique (Chang and Choudhury, 1978). This technique is based on the principle that the radiation emerging from a semi-infinite, plane-parallel medium is invariant with respect to addition (or subtraction) of layers of arbitrary thickness to (or from) the medium. This technique enables the radiative-transfer equation to be solved numerically using recurrence relationships.

By this method, the emerging brightness temperatures are calculated for snow-packs with different parameters. Assumptions are that the total snow depth is $30 \mathrm{~cm}$, the underlying soil is frozen, and the snow-pack is dry. The snow grains scatter the electromagnetic radiation incoherently and are assumed to be spherical in shape and randomly spaced within the snow-pack. This two-layer model allows for assignment of different top and bottom layer thicknesses, grain-sizes, and densities. Further discussions on the assumptions of the microscopic model can be found in Chang and others (1976).

Because the grains in the depth-hoar layer are hollow and cup-shaped and not spherical, they are not as effective at scattering upwelling microwave radiation as are spherical grains. Thus, when considering the microwave scattering, the effective diameter of the grains is considerably smaller than the actual diameter of the largest dimension of a depth-hoar crystal. Using the model, employment of grain-sizes in the lower layer comparable to those typically observed in nature yielded brightness temperatures that were far too low as compared to observed brightness temperatures.

An effective snow-grain diameter of $1.40 \mathrm{~mm}$ for the bottom or depth-hoar layer was used in the model. Use of this diameter rendered $T_{\mathrm{B}} \mathrm{S}$ that were comparable to those observed by the SMMR in the three study areas. The actual and effective grain-size diameter should be approximately equal in the top layer. This was assumed to be $0.50 \mathrm{~mm}$.

In addition to the fact that the effective scattering size is smaller because of the configuration of the depth-hoar crystal, the average grain-size in the depth-hoar layer is

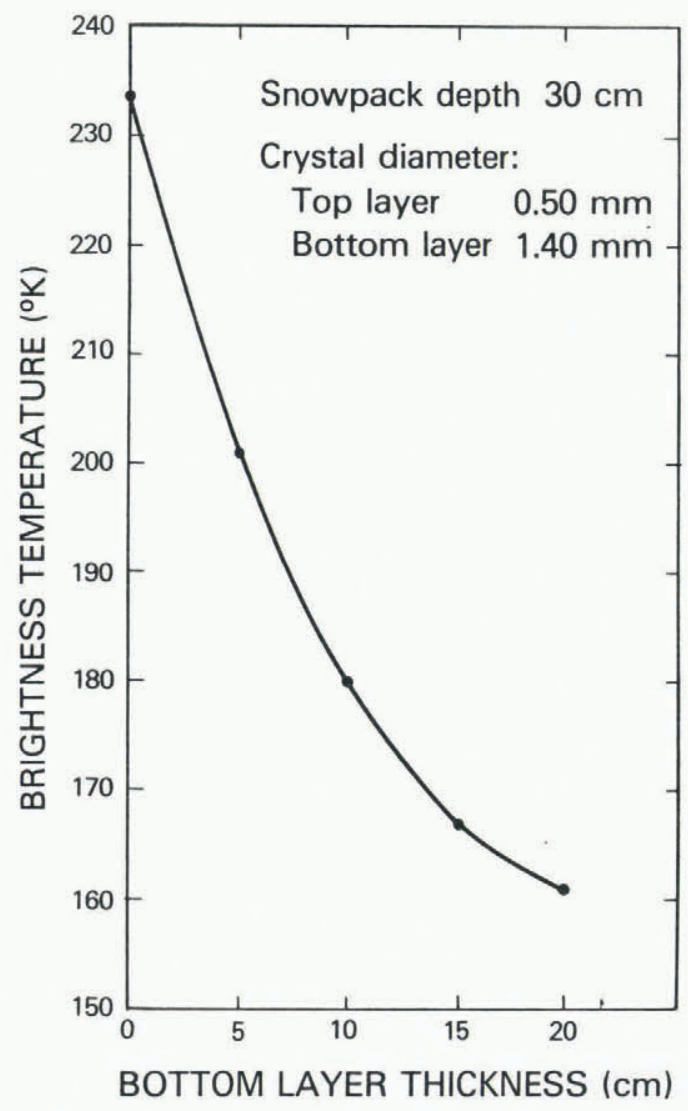

Fig. 8. Calculated $37 \mathrm{GHz}$ (horizontal polarization) brightness temperatures for dry snow over frozen ground showing the effect of changing the thickness of the depth-hoar layer. 
much lower than the 5-10 mm maximum size reported by Benson and others (1975).

Results of the modeling are shown in Figure 8. As expected, brightness temperatures decrease with increasing thickness of the bottom or depth-hoar layer. Calculated brightness temperatures shown in Figure 8 are comparable to observed brightness temperatures in the study areas in mid to late winter when the snow-packs are mature. Model results show a sharp (33K) lowering of the $T_{\mathrm{B}}$ when even a thin $(5 \mathrm{~cm})$ depth-hoar layer develops. As the depth-hoar layer increases in thickness, the rate of change in brightness temperature decreases as seen in Figure 8.

Calculated $T_{\mathrm{B}} \mathrm{s}$ compare favorably with observed values for mature snow-packs in three of the four winters studied. (In the 1981-82 winter $T_{\mathrm{B}} \mathrm{s}$ were approximately $20 \mathrm{~K}$ lower than in the other three years.) The actual thickness of the depth-hoar layer was not measured. However, if one assumes that the thickness of the depth-hoar layer was $5 \mathrm{~cm}$ in area $A$ and $10 \mathrm{~cm}$ in area $C$, then the model-generated $T_{\mathrm{B}} \mathrm{S}$ fall within the range (the high end of the range) of observed $T_{\mathrm{B}} \mathrm{s}$. The calculated $T_{\mathrm{B}}$ for a snow-pack with a $5 \mathrm{~cm}$ depth-hoar layer is $201 \mathrm{~K}$ and the range of observed $T_{\mathrm{B}} \mathrm{s}$ in area $\mathrm{A}$ is $181-201 \mathrm{~K}$ (excluding the 1981-82 winter). For a snow-pack with a $10 \mathrm{~cm}$ depth-hoar layer, the calculated $T_{\mathrm{B}}$ is $180 \mathrm{~K}$ and the range of observed brightness temperatures in area $\mathrm{C}$ is $165-181 \mathrm{~K}$.

The magnitude of decrease in calculated $T_{\mathrm{B}} \mathrm{s}$ between depth-hoar layer thicknesses of 5 and $10 \mathrm{~cm}$ is $21 \mathrm{~K}$. This approximates the difference in $T_{\mathrm{B}}$ observed using SMMR data between areas $\mathrm{A}$ and $\mathrm{C}$ where $T_{\mathrm{B}}$ differences are approximately $20 \mathrm{~K}$.

\section{CONCLUSION}

The fact that $37 \mathrm{GHz}$ passive microwave radiation scattering increases with snow grain-size has been discussed in terms of the accumulation rate of polar firn on the Greenland and Antarctic ice sheets. Observations and calculations have shown this to be a dominant factor in the interpretation of passive microwave data of seasonal snowpacks as well.

Results of this study indicate that the depth-hoar layer, with its very large snow grain-sizes, can be detected using Nimbus-7 Scanning Multichannel Microwave Radiometer (SMMR) $37 \mathrm{GHz}$ passive microwave data and that geographic variations in the thickness of the depth-hoar layer may also be observable.

Employment of a radiative-transfer model shows the effect of varying the thickness of the depth-hoar layer on the calculated brightness temperatures. A calculated decrease in $T_{\mathrm{B}}$ of $21 \mathrm{~K}$ caused by increasing the thickness of the lower layer from 5 to $10 \mathrm{~cm}$ approximates the observed changes in $T_{\mathrm{B}}$ (between coastal and inland sites) seen on the SMMR data of the Arctic Coastal Plain of Alaska. Because the depth-hoar crystals are hollow and cup-shaped, they are not as effective at scattering the upwelling radiation as are spherical grains. The effective scattering size of the depth-hoar crystals is considerably lower than the diameter of the largest dimension of the crystal as measured in the snow-pack.

\section{ACKNOWLEDGEMENT}

The authors would like to thank Drs R. Gurney and T. Schmugge for their reviews of this paper.

\section{REFERENCES}

Benson, C.S., and Trabant, D.C. 1973. Field measurements on the flux of water vapour through dry snow. (In The role of snow and ice in hydrology. Proceedings of the Banff symposia, September 1972. A contribution to the International Hydrological Decade. Paris, UNESCO; Geneva, WMO; Budapest, IAHS, Vol. 1, p. 291-98. (Publication No. 107 de l'Association Internationale d'Hydrologie Scientifique.))

Benson, C., and others. 1975. Observations on the seasonal snow cover and radiation climate at Prudhoe Bay, Alaska during 1972, by C. Benson, B. Holmgren, R. Timmer, G.
Weller, and S. Parrish. (In Brown, J., ed. Ecological investigations of the tundra biome in the Prudhoe Bay region, Alaska. Fairbanks, University of Alaska, p. 13-50. (Biological Papers. Special Report, No. 2.))

Brown, J., and others. 1975. Selected climatic and soil thermal characteristics of the Prudhoe Bay region, by $J$. Brown, R.K. Haugen, and S. Parrish. (In Brown, J., ed. Ecological investigations of the tundra biome in the Prudhoe Bay region, Alaska. Fairbanks, University of Alaska, p. 3-11. (Biological Papers. Special Report, No. 2.))

Chang, A.T.C., and Choudhury, B.J. 1978. Microwave emission from polar firn. Washington DC, National Aeronautics and Space Administration. (MASA Technical Paper 1212.)

Chang, A.T.C., and others. 1976. Microwave emission from snow and glacier ice, by A.T.C. Chang, P. Gloersen, T. Schmugge, T.T. Wilheit, and H.J. Zwally. Journal of Glaciology, Vol. 16, No. 74, p. 23-39.

Chang, A.T.C., and others. 1982. Snow water equivalent estimation by microwave radiometry, by A.T.C. Chang, J.L. Foster, D.K. Hall, A. Rango, and B.K. Hartline. Cold Regions Science and Technology, Vol. 5, No. 3, p. 259-67.

Colbeck, S.C. 1982[a]. An overview of seasonal snow metamorphism. Reviews of Geophysics and Space Physics, Vol. 20, No. 1, p. 45-61.

Colbeck, S.C. 1982[b]. Growth of faceted crystals in a snow cover. CRREL Report 82-29.

Foster, J.L., and others. 1984. An overview of passive microwave snow research and results, by J.L. Foster, D.K Hall, A.T.C. Chang, and A. Rango. Reviews of Geophysics and Space Physics, Vol. 22, p. 195-208.

Giddings, J.C., and LaChapelle, E. 1962. The formation rate of depth hoar. Journal of Geophysical Research, Vol. 67, No. 6, p. 2377-83.

Gloersen, P., and Barath, F. 1977. A scanning multichannel microwave radiometer for Nimbus-G and Seasat-A. IEEE Journal of Oceanic Engineering, Vol. OE-2, p. 172-78.

Hall, D.K., and others. 1984. Nimbus-7 SMMR polarization responses to snow depth in the mid-western U.S., by D.K. Hall, J.L. Foster, and A.T.C. Chang. Nordic Hydrology, Vol. 15 , p. 1-8.

Holmgren, B., and others. 1975. A study of the breakup on the Arctic slope of Alaska by ground, air and satellite observations, by B. Holmgren, C. Benson, and G. Weller. (In Weller, G., and Bowling, S.A., ed. Climate of the Arctic. Twenty-Fourth Alaska Science Conference, Fairbanks, Alaska, August 15 to 17, 1973. Fairbanks, University of Alaska, p. 358-66.)

Langham, E.J. 1981. Physics and properties of snowcover. (In Gray, D.M., and Male, D.H., ed. Handbook of snow; principles, processes, management and use. Toronto, etc., Pergamon Press, p. 275-337.)

Marbouty, D. 1980 . An experimental study of temperature-gradient metamorphism. Journal of Glaciology, Vol. 26, No. 94, p. 303-12.

NOAA 1979-83. Climatological Data, Alaska, Vol. 65-69. Asheville, NC, National Oceanic and Atmospheric Administration. National Climatic Center.

Rango, A., and others. 1979. The utilization of spaceborne microwave radiometers for monitoring snowpack properties, by A. Rango, A.T.C. Chang, and J.L. Foster. Nordic Hydrology, Vol. 10, No. 1, p. 25-40.

Santeford, H.S. 1979. Snow soil interactions in interior Alaska. (In Colbeck, S.C., and Ray, M., ed. Proceedings of a Meeting on Modeling of Snow Cover Runoff, 26-28 September 1978. Hanover, NH, U.S. Army CRREL, p. 311-18.)

Slaughter, C.W., and Crook, A.G. 1974. The Arctic and subarctic seasonal snowpack: research and management approaches in Alaska. (In Santeford, H.S., and Smith, J.L., comps. Advanced concepts and techniques in the study of snow and ice resources. Washington, DC, National Academy of Sciences, p. 273-82.)

Weeks, W.F. 1981. Sea ice: the potential of remote sensing. Oceanus, Vol. 24, No. 3, p. 39-48.

Zwally, H.J., and Gloersen, P. 1977. Passive microwave images of the polar regions and research applications. Polar Record, Vol. 18, No. 116, p. 431-50. 